\title{
Effect of pulsed electric field treatment on enzymatic hydrolysis of proteins of Scenedesmus almeriensis
}

\author{
Sahar Akaberi ${ }^{\mathrm{a}, *}$, Christian Gusbeth ${ }^{\mathrm{a}}$, Aude Silve ${ }^{\mathrm{a}}$, Divya Senthil Senthilnathan ${ }^{\mathrm{a}}$, \\ Elvira Navarro-López ${ }^{\mathrm{b}}$, Emilio Molina-Grima ${ }^{\mathrm{b}}$, Georg Müller ${ }^{\mathrm{a}}$, Wolfgang Frey ${ }^{\mathrm{a}}$ \\ ${ }^{a}$ Karlsruhe Institute of Technology, Institute for Pulsed Power and Microwave Technology (IHM), Hermann-von-Helmholtz-Platz 1, Geb. 630, 76344 Eggenstein- \\ Leopoldshafen, Germany \\ ${ }^{\mathrm{b}}$ Department of Chemical Engineering, University of Almería, 04120 Almería, Spain
}

\section{A R T I C L E I N F O}

\section{Keywords:}

Pulsed electric field treatment

Microalgae biomass

Enzymatic hydrolysis

SDS-PAGE

Amino acids concentrate

\begin{abstract}
A B S T R A C T
Amino acids concentrates derived from microalgae biomass through enzymatic protein hydrolysis can improve plant growth by saving the energy that is required for amino acid synthesis from conventional mineral fertilizer resources. To obtain high enzymatic hydrolysis yields, pre-treatment of microalgae biomass prior to enzymatic hydrolysis is suggested for facilitating enzyme access to proteins.

Pulsed electric field (PEF) treatment was introduced as a pre-treatment to fresh and concentrated ( $50 \mathrm{~g} \cdot \mathrm{kg}_{\text {sus }}{ }^{-1}$ to $80 \mathrm{~g} \cdot \mathrm{kg}_{\text {sus }}{ }^{-1}$ ) Scenedesmus almeriensis biomass prior to enzymatic hydrolysis. The concentrated microalgae suspension was treated at an initial conductivity of $\sigma=1 \mathrm{mS} \cdot \mathrm{cm}^{-1}$ with $1 \mu$ s long pulses at an electric field strength of $40 \mathrm{kV} \cdot \mathrm{cm}^{-1}$ and a treatment energy of $75 \mathrm{~kJ} \cdot \mathrm{kg}_{\text {sus }}{ }^{-1}$ and $150 \mathrm{~kJ} \mathrm{~kg}_{\text {sus }}{ }^{-1}$. For benchmarking, additional biomass samples were processed by high pressure homogenization (HPH) at $2 \mathrm{kbar}$ and up to 5 passes. Enzymatic hydrolysis was performed by applying the commercial enzymes Alcalase $2.5 \mathrm{~L}$ and Flavourzyme $1000 \mathrm{~L}$ for $180 \mathrm{~min}$. The amino acids content in supernatant was determined by using the ortophthaldialdehyde (OPA) assay.

PEF treatment at both energy inputs and HPH treatment at $2 \mathrm{kbar}, 5$ passes, revealed the same hydrolysis kinetics and the same final value of the degree of hydrolysis $(\mathrm{DH})$ of $50 \% \pm 2 \%$. The energy demand for PEF pre-treatment amounts to $0.75 \mathrm{MJ} \cdot \mathrm{kg}_{\mathrm{dw}}{ }^{-1}$ when processing biomass at $100 \mathrm{~g}_{\mathrm{dw}} \cdot \mathrm{l}^{-1}$. After both pretreatments, incomplete protein hydrolysis could be detected by SDS-PAGE analysis of residual biomass. Most feasible, hydrophobic protein fractions and protein aggregation impede complete protein hydrolysis by the applied enzyme cocktail.

Since PEF treatment preserves cell shape and biomass separability and thus enables cascade processing, it is suggested as alternative downstream processing method for the production of amino acids concentrates from microalgae biomass.
\end{abstract}

\section{Introduction}

Microalgae have been considered as a promising source of food, feed, and medicine in recent years, because of their high contents of proteins, carbohydrates, lipids, as well as pigments, vitamins and minerals [1,2]. Proteins, for instance, are the major components of various microalgae species if cultivated under nitrogen-sufficient conditions and notably, the amino acid composition of microalgal proteins is comparable to most food proteins [3] promising an alternative source of proteins for human and animal nutrition.
Besides humans and animals, plants can also make use of microalgal proteins as a nitrogen source. However, few plants are able to uptake proteins without the assistance of symbioses microorganisms [4]. For instance, the green microalgae biomass Chlorella vulgaris is applied as soil fertilizer that improves shoot and root growth in wheat Triticum aestivum L. [5]. It has been shown that Acutodesmus dimorphus biomass can be applied to tomato seedlings to enhance branch and flower development [6].

Since proteins even in their primary structure are not as effective as they are in the form of free amino acids, a strategy to make them

Abbreviations: PEF, pulsed electric field; HPH, high pressure homogenization; DH, degree of hydrolysis; EH, enzymatic hydrolysis; SDS-PAGE, sodium dodecyl sulfate-polyacrylamide gel electrophoresis

* Corresponding author.

E-mail address: sahar.akaberi@kit.edu (S. Akaberi). 
useful for various purposes is to hydrolyse them into amino acids [8]. Protein hydrolysis can be performed either chemically, or enzymatically by using commercial proteases. Enzymatic hydrolysis $(\mathrm{EH})$ is preferable since, on the one hand, chemically sensitive amino acids remain intact through the hydrolysis and, on the other hand, there is no need for neutralization as it is in the case of acidic hydrolysis which produces higher ash contents [7]. In food or pharma industries, raw protein material from plants, animals, or even from marine organisms is hydrolyzed enzymatically for the production of bioactive peptides [8-10]. This product, known as amino acids concentrate, can also be used for agricultural purposes to supply the plant with a concentrate of free amino acids. Amino acids uptake enables plants to save a considerable amount of energy which would be required for amino acid synthesis [11]. Although few plants make use of this nutritional energy gain by converting proteins into amino acids either by releasing proteolytic enzymes via roots or with the enzymatic help of soil microbes [4].

Comparable strategies can also be pursued on proteins originated from microalgae. In fact, EH of proteins from microalgae biomass has already been investigated to produce food additives [12], pharmaceuticals [13], or plant fertilizers [11].

Specifically for plants, it has been shown that the amino acids concentrate obtained through $\mathrm{EH}$ from microalgae biomass Scenedesmus almeriensis significantly improved root growth and flower development of Petunia plants [14]. So far, EH of microalgae biomass has been performed using freeze-dried biomass [11,12]. However, freeze-drying of biomass is not applicable at an industrial level since energy consumption generates prohibitive costs. Furthermore, it appears that cell disruption prior to $\mathrm{EH}$ is required, hypothetically because a pre-treatment might facilitate protein release, and in consequence the enzymatic hydrolysis process [11]. It is well known that the conventional cell disruption methods such as high pressure homogenization ( $\mathrm{HPH})$, or bead milling (BM) are energy demanding. Considering robust microalgae species, the best reported values at laboratory-scale are 3.4 and $3.6 \mathrm{MJ} \cdot \mathrm{kg}_{\mathrm{dw}}$, for $\mathrm{HPH}$ and $\mathrm{BM}$, respectively $[15,16]$. In addition, the debris generated by those methods can also be an issue, especially when further fractionation of the biomass is intended.

Despite the potentials that this product could offer as an environmentally friendly fertilizer, there are still difficulties toward achieving an economic product due to the technical difficulties mentioned above and to the costs of the pre-treatment, or of the enzymes required for hydrolysis. Pulsed electric field (PEF) application has been suggested as a promising technology with the potential to tackle the technical issues while maintaining costs reasonably low. Introducing biological cells to an external electric field causes an increase of transmembrane voltage, which leads to the permeabilization of the cell membrane. With respect to the applied energy, the electric field strength, and pulse duration, permeabilization can be either reversible or irreversible i.e. leading to cell death [17]. Electroporation ensures cell membrane permeabilization which on the one side, leads to the release of intracellular compounds, and on the other side, also enables the transfer of compounds from extracellular matrix into the cells. During the last decades, PEF treatment has been successfully utilized for the extraction of intracellular valuables even at an industrial scale [18]. Hence, in the present work, PEF treatment has been chosen as a pre-treatment method prior to enzymatic hydrolysis since it is expected to facilitate enzyme access into the cells in order to cleave intracellular proteins. In addition, released proteins are expected to be cleaved easier by enzymes. The influence of PEF treatment on the yield of the EH has been studied in order to assess its potential benefit. The whole study was performed on Scenedesmus almeriensis. This protein-rich strain (50-55\% of dry weight) exhibits high temperature and irradiance tolerance, which makes it an attractive candidate for outdoor cultivation and large-scale microalgae production $[19,20]$.

\section{Material and methods}

\subsection{Microalgae biomass}

The microalga $S$. almeriensis was isolated in fresh water from a greenhouse located in Almeria, Spain. This strain is deposited in the Culture Collection of Algae and Protozoa of the Centre for Hydrology and Ecology, Ambleside, U.K., code CCAP 276/24. Cultivation of these microalgae was carried out in round flasks using Arnon medium $1 \times$ [21], and $\mathrm{pH} 9-10$ at $25^{\circ} \mathrm{C}$. The flasks were bubbled with air at the rate of $5000 \mathrm{~cm}^{3} \cdot \mathrm{min}^{-1}$ to prevent cell sedimentation, and illuminated $24 \mathrm{~h}$ at $50-80 \mu \mathrm{mol} \cdot \mathrm{m}^{-2} \cdot \mathrm{s}^{-1}$. It should be mentioned that this cultivation was limited by $\mathrm{CO}_{2}$. In order to have a high amount of proteins for the $\mathrm{EH}$, the biomass was harvested after 7 days of cultivation, while cells were still in the exponential phase of growth. When higher amount of biomass was required, cultivation was carried out in the Arnon medium $2 \times, \mathrm{pH} 8$ in a 251 bubble column annular photobioreactor, illuminated $24 \mathrm{~h}$ at $250 \mu \mathrm{mol} \cdot \mathrm{m}^{-2} \cdot \mathrm{s}^{-1}$ with a temperature maintained at $25^{\circ} \mathrm{C}$. The cultivation was aerated with $5000 \mathrm{~cm}^{3} \cdot \mathrm{min}^{-1}$ of air supplemented with $25 \mathrm{~cm}^{3} \cdot \mathrm{min}^{-1}$ of $\mathrm{CO}_{2}$. In both cases, microalgae suspension was concentrated after the harvest using a centrifuge (swinging-bucket rotor, $3200 \times g$ ). In order to reduce the energy requirement of PEF treatment it is suggested to reduce the conductivity of the microalgae suspension [22]. Since the initial conductivity of our microalgae suspension was at $4.2 \mathrm{mS} \cdot \mathrm{cm}^{-1}$, a washing step was performed in order to adjust the conductivity value of the microalgae suspension at $1.5 \mathrm{mS} \cdot \mathrm{cm}^{-1}$. A follow-up of the conductivity value over time confirmed that the washing step did not damage the cells by inducing an osmotic shock.

\subsection{Pre-treatment of the biomass}

Fresh microalgae biomass was processed by $\mathrm{PEF}$ and for comparison by high pressure homogenization (HPH) as a benchmark. PEF treatment of microalgae suspension was carried out using a continuous flow treatment chamber and a transmission line based pulse generator developed at the Institute of Pulsed Power and Microwave Technology (Karlsruhe Institute of Technology, Germany) and described in [1]. More details about our PEF treatment chamber for the continuous flow processing of the biomass can be found in [22]. To study the effect of PEF treatment on $S$. almeriensis, the pulse parameters from Eing et al. [23] were chosen since they were shown to be efficient on Auxenochlorella protothecoides. As a starting point a specific treatment energy of $150 \mathrm{~kJ} \cdot \mathrm{kg}_{\text {sus }}{ }^{-1}$ has been applied, since Goettel et al. [1] have shown on Auxenochlorella protothecoides that PEF treatment with higher energies has no further advantages. In addition, PEF treatment at lower energy of $75 \mathrm{~kJ} \cdot \mathrm{kg}_{\text {sus }}{ }^{-1}$ has been tested to assess the possibility to further reduce the energy demand for PEF-treatment of wet $S$. almeriensis biomass in particular. PEF treatment was applied using pulses of $1 \mu$ s duration, an electric field strength of $40 \mathrm{kV} \cdot \mathrm{cm}^{-1}$ and a treatment energy of either $75 \mathrm{~kJ} \cdot \mathrm{kg}_{\text {sus }}{ }^{-1}$ or $150 \mathrm{~kJ} \cdot \mathrm{kg}_{\text {sus }}{ }^{-1}$. The energy input of PEF treatment was selected by solely adjusting the pulse repetition frequency at $3 \mathrm{~Hz}$ for $150 \mathrm{~kJ} \cdot \mathrm{kg}_{\text {sus }}{ }^{-1}$ or at $1.5 \mathrm{~Hz}$ for $75 \mathrm{~kJ} \cdot \mathrm{kg}_{\text {sus }}{ }^{-1}$ at a constant suspension mass flow through the treatment chamber of $6 \mathrm{ml} \cdot \mathrm{min}^{-1}$ (for details see $[22,23])$. HPH treatment was performed by using an EmulsiFlex-C3 homogenizer (Avestin, Canada). To ensure maximum cell disruption, HPH samples were processed at $2 \mathrm{kbar}$ and 5 passes. PEF treated, HPH treated, along with untreated biomass were further processed by $\mathrm{EH}$.

\subsection{Cell dry weight}

To determine the cell dry weight, the conventional drying method using a circulating air oven (U LP 500, Memmert, Germany) was followed. $5 \mathrm{ml}$ of cell suspension were weighed in an aluminium plate using a fine balance (Mettler AE 163) (mass of wet algae). The same volume was also centrifuged at $5000 \times g$ for $5 \mathrm{~min}$. The supernatant was weighed and termed as the mass of wet medium. Both plates were dried 
in an oven at $85{ }^{\circ} \mathrm{C}$ for $2 \mathrm{~h}$. After drying, the weight of dry algae and dry medium were determined. The cell dry weight (CDW, $\left[\mathrm{g} \cdot \mathrm{kg}_{\text {sus }}{ }^{-1}\right]$ ) is calculated using the Eq. (1).

$C D W=\left(\frac{\text { mass of dry algae }}{\text { mass of wet algae }}-\frac{\text { mass of dry medium }}{\text { mass of wet medium }}\right) \times 1000$

\subsubsection{Conductivity measurements after PEF treatment}

The conductivity $\sigma\left(\mathrm{mS} \cdot \mathrm{cm}^{-1}\right)$ of the microalgae suspension was measured using a conductivity meter (WTW, cond 3310), without automatic temperature compensation. The temperature $\mathrm{T}\left[{ }^{\circ} \mathrm{C}\right]$ was recorded simultaneously with the conductivity according to [20]. The equivalent conductivity at $20^{\circ} \mathrm{C}, \sigma_{20}\left[\mathrm{mS} \cdot \mathrm{cm}^{-1}\right]$, was calculated for the microalgae suspension using Eq. (2), where $\alpha_{20}$ is the temperature coefficient of variation at $20^{\circ} \mathrm{C}$ according to [24]. The coefficient $\alpha_{20}$ was obtained experimentally by measuring the conductivity of the microalgae suspension within a temperature range from $22^{\circ} \mathrm{C}$ to $35^{\circ} \mathrm{C}$ (data not shown). The coefficient $\alpha_{20}$ had a value of $2.38 \%$ per degree of centigrade.

$\sigma_{20}=\sigma_{T} \frac{1}{1+\alpha_{20}(T-20)}$

\subsection{Total protein content}

In order to evaluate the total protein content of the microalgae biomass a chemical extraction was performed at a high temperature using sodium hydroxide [25]. From the fresh microalgae suspension concentrated to at least $50 \mathrm{~g} \cdot \mathrm{kg}_{\text {sus }}{ }^{-1}$, a volume containing $5 \mathrm{mg}$ of microalgae biomass was resuspended in $2 \mathrm{ml}$ sodium hydroxide $(1 \mathrm{M})$ and incubated at $95^{\circ} \mathrm{C}$ for $1 \mathrm{~h} \mathrm{[26].} \mathrm{After} \mathrm{this} \mathrm{incubation,} \mathrm{samples} \mathrm{were}$ cooled to ambient temperature. This suspension was centrifuged at $10,000 \times g$ for $10 \mathrm{~min}$, and the supernatant was processed for protein determination applying a modified Lowry method $\left(D C^{\mathrm{TM}}\right.$ Protein Assay, BioRad), using bovine serum albumin as standard [25]. Total protein content determined from all treated biomasses was $50.8 \% \pm 2.9$ (SE) of dry weight.

\subsection{Enzymatic hydrolysis and degree of hydrolysis}

EH was carried out according to [11]. Hydrolysis reactors consisted of $50 \mathrm{ml}$ wide-necked jars with the screw cap (Roth, Germany) provided with two ports that were drilled for pH-electrode and pipette access. Temperature and agitation were adjusted using a water bath and a magnetic stirrer with heating function (neoLab, Germany). After transferring the biomass into the reactor, the temperature was adjusted to $50^{\circ} \mathrm{C}$. Sodium hydroxide $(1 \mathrm{M})$ was used to adjust the $\mathrm{pH}$ at 8 .

For hydrolysis, two commercial proteases, Alcalase (subtilisin) $2.5 \mathrm{~L}$ (Novozyme, Denmark), and Flavourzyme 1000 L (Novozyme, Denmark) were added at $3 \%(\mathrm{v} \cdot \mathrm{w})$ each with regard to cell dry weight of the biomass, i.e. enzyme to substrate (E/S) ratio of $\sim 6 \%$, since total protein content determined from all treated biomasses was $50.8 \% \pm 2.9$ (SE) of dry weight. According to McDonald [27], Alcalase is classified as an endopeptidase. Whereas, Merz et al. [28] showed that Flavourzyme is a mixture of seven different proteases with exo- and endopeptidase activity along with one amylase.

Hydrolysis reaction was performed for $180 \mathrm{~min}$. The rate of hydrolysis was monitored by taking samples every $60 \mathrm{~min}$ in which enzymes were immediately thermally deactivated at $80^{\circ} \mathrm{C}$ for $10 \mathrm{~min}$. The supernatant, containing free amino acids, was separated from the residual biomass by centrifugation at $10,000 \times g$ for $10 \mathrm{~min}$. The amino acid content was measured using orto-phthaldialdehyde (OPA) assay using serine as standard [29]. Degree of hydrolysis (DH) is a definition used to show the rate of the hydrolysis reaction (Eq. (3)). It is defined as the number of cleaved peptide bonds over the total number of peptide bonds presented in the sample.

Degree of Hydrolysis (\%)

$$
=\frac{\text { number of cleaved peptide bonds }(\text { Amino Acids content })}{\text { Total number of peptide bonds }(\text { Protein content })} \times 100
$$

\subsection{Determination of the non-hydrolysed proteins after $E H$}

To determine the proteins that remain unaffected after $180 \mathrm{~min}$ of the hydrolysis, $1 \mathrm{ml}$ of the hydrolysate was collected. After removing the supernatant (containing amino acids concentrate) by centrifugation for $10 \mathrm{~min}$ at $10,000 \times \mathrm{g}$, the residual biomass was collected. The remaining non-hydrolysed proteins were extracted and subsequently analysed by SDS-PAGE (sodium dodecyl sulfate-polyacrylamide gel electrophoresis). The protein extraction was performed by homogenizing the residual biomass in $1 \mathrm{ml}$ of Tris-Triton buffer containing $20 \mathrm{mM}$ Tris, $200 \mathrm{mM} \mathrm{NaCl}, 2 \%$ Triton X-100, 2 mM EGTA, 2 mM EDTA, $20 \%$ Glycerol, $0.2 \%$ SDS, and $1 \%$ sodium deoxycholate, pH 7.4 for $30 \mathrm{~min}$ at $95^{\circ} \mathrm{C}$. Cell lysates were first spun down at $10,000 \times \mathrm{g}$ for $10 \mathrm{~min}$ to remove debris. Then, the supernatant was mixed with $4 \times$ Laemmli buffer (200 mM Tris-HCl, 8\% ( $w / v)$ SDS, 40\% ( $v / v)$ Glycerol, $4 \%(\mathrm{v} / \mathrm{v}) \quad \beta$-mercaptoethanol, $0.8 \%(\mathrm{w} / \mathrm{v})$ bromophenol blue), and subsequently heated at $95^{\circ} \mathrm{C}$ for $15 \mathrm{~min}$ [30]. After loading $25 \mu \mathrm{l}$ of sample onto the SDS-PAGE gel (12\%) submerged in running buffer ( $25 \mathrm{mM}$ Glycine, $192 \mathrm{mM}$ Tris, $0.1 \%$ SDS), the gel was run for $2 \mathrm{~h}$ at 100 V. Finally, the gel was stained with coomassie blue colloidal [31] overnight and washed with distilled water on the next day.

\subsection{Microscopy analysis}

Images were recorded with a Zeiss Axioplan 2 microscope using a Plan-Apochromat $\times 63 / 1.44$ DIC objective operated via the Zen 2012 (Blue edition) software platform.

\section{Results}

\subsection{Effect of PEF treatment on microalgae biomass}

One of the expected changes following PEF treatment is the increase of conductivity of the microalgae suspension, which happens due to the leakage of ions or small charged molecules. Therefore, conductivity changes over time were followed in order to evaluate whether the PEF treatment at both energy inputs were efficient on S. almeriensis. The recorded conductivity changes of the microalgae suspension were corrected for the temperature increase caused by Joule heating, and normalised to the reference temperature of $20^{\circ} \mathrm{C}$ using Eq. (2). As expected, PEF treated microalgae biomass at both energy inputs showed an increase in conductivity in comparison to the untreated biomass (Fig. 1). Immediately after submitting the microalgae cells to the PEF treatment, the conductivity increased by a factor of 2 over the conductivity of the untreated biomass for energy input at $150 \mathrm{~kJ}^{\mathrm{kg}} \mathrm{kgus}^{-1}$, as well as the energy input at $75 \mathrm{~kJ} \mathrm{~kg}_{\text {sus }}{ }^{-1}$. Within $24 \mathrm{~h}$, the conductivity of the control slightly reduced due to prolonged nutrient uptake, whereas the conductivity of the PEF-treated samples continuously increased and finally reached 3.5 times the value of conductivity of the untreated control biomass (Fig. 1). In other words, the increase of the conductivity of the PEF-treated sample for the energy input at $150 \mathrm{~kJ} \cdot \mathrm{kg}_{\text {sus }}{ }^{-1}$ and at $75 \mathrm{~kJ} \cdot \mathrm{kg}_{\text {sus }}{ }^{-1}$ was identical.

\subsection{Effect of pre-treatment on protein release in suspension}

To study the effect of pre-treatment on the release of intracellular proteins in the suspension, fresh $S$. almeriensis biomass was treated with PEF or HPH. In order to maximize protein release after PEF treatment the biomass was incubated for $2 \mathrm{~h}$. Regarding $\mathrm{HPH}$ treatment, the 


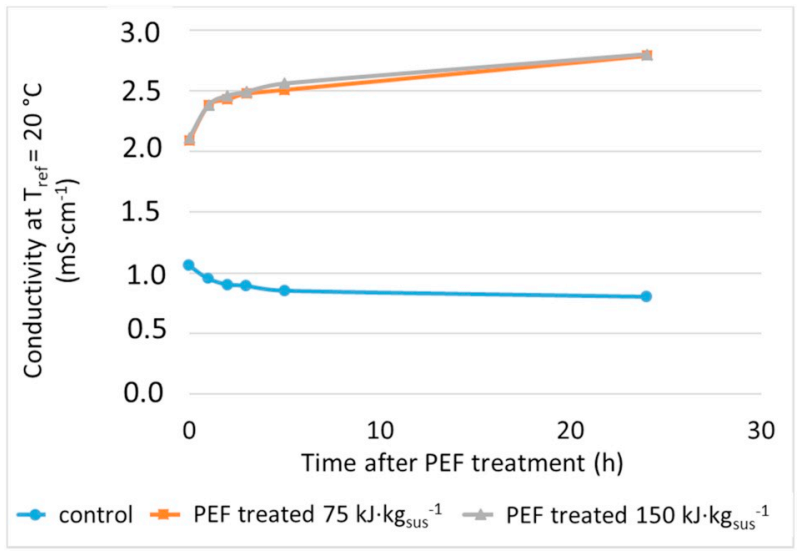

Fig. 1. Conductivity of S. almeriensis suspension after PEF treatment. Biomass obtained from annular PBR and concentrated to $97 \mathrm{~g} \cdot \mathrm{kg}_{\text {sus }}{ }^{-1}$. PEF treated at an energy input of $75 \mathrm{~kJ} \cdot \mathrm{kg}_{\text {sus }}{ }^{-1}$ and $150 \mathrm{~kJ}^{-\mathrm{kg}_{\text {sus }}}{ }^{-1}$, as well as untreated S. almeriensis biomass were incubated for $24 \mathrm{~h}$, and conductivity values were plotted over time.

amount of released proteins was determined after different number of passes (Fig. 2). Although the highest amount of proteins could already be obtained after 3 passes, the number of passes through the homogenizer was selected to be $n=5$, to ascertain a maximum amount of proteins to be released into the suspension. For HPH treatment, the maximum release of proteins into the suspension was $54 \%$ of dry weight. However, after PEF treatment and $2 \mathrm{~h}$ of incubation only $1.15 \%$ of dry weight of released proteins could be detected.

\subsection{EH using PEF treated $S$. almeriensis biomass}

In order to investigate the effect of PEF treatment on the yield of hydrolysis, in the first step of this study, the $\mathrm{EH}$ has been performed using freshly harvested $S$. almeriensis biomass obtained from flasks and concentrated to $50 \mathrm{~g} \cdot \mathrm{kg}_{\text {sus }}{ }^{-1}$. Experiments included some biomass treated with $\mathrm{HPH}$, which acted as a positive control. Untreated microalgae biomass and PEF or HPH treated biomass were submitted to EH using commercial proteases. Both proteases (Alcalase and Flavourzyme) were added at the beginning of the reaction. Free amino acids that are released during hydrolysis, acidify the hydrolysis suspension, thus reducing the $\mathrm{pH}$. However, $\mathrm{EH}$ was performed for $180 \mathrm{~min}$ at a constant $\mathrm{pH}$ of 8 adjusted by adding sodium hydroxide on demand. As the results show, PEF and HPH treatments could significantly increase the degree of hydrolysis just after $60 \mathrm{~min}$ of hydrolysis with $39 \%$ and $40 \%$ degree of hydrolysis, respectively (Fig. 3A and Supplementary file 1). Although both pre-treatment methods initially showed a faster increase of the degree of hydrolysis, the untreated biomass also reached a relatively high $\mathrm{DH}(40.8 \%)$ after $180 \mathrm{~min}$ of the $\mathrm{EH}$, in comparison to $\mathrm{DH}$ of $50.6 \%$ and $48.5 \%$ obtained by PEF-treatment and HPH-treatment, respectively. It can be seen that the $\mathrm{DH}$ of untreated biomass increased steadily over the time and partially compensated for the initial slower efficiency (Fig. 3A and Supplementary file 1).

The same procedure was performed on microalgae cultivated in the annular PBR without any growth limitation. In addition, increasing the concentration of the treated biomass suspension enables further reduction of PEF energy demand [1]. Thus, in that case, the concentration of the treated biomass suspension was increased to $80 \mathrm{~g}^{\mathrm{k} g} \mathrm{gsus}^{-1}$. In order to study the influence of PEF treatment energy on the degree of hydrolysis, samples were treated at $150 \mathrm{~kJ} \cdot \mathrm{kg}_{\text {sus }}{ }^{-1}$ and $75 \mathrm{~kJ} \cdot \mathrm{kg}_{\text {sus }}{ }^{-1}$.

The hydrolysis degrees obtained after $180 \mathrm{~min}$ for the two PEFtreatment energies of $75 \mathrm{~kJ} \cdot \mathrm{kg}_{\text {sus }}{ }^{-1}$ and $150 \mathrm{~kJ}^{\circ} \mathrm{kg}_{\text {sus }}{ }^{-1}$ were $46.5 \%$ and $47.7 \%$, respectively. It can be ascertained that the lower energy input achieved a comparable DH as obtained with the higher energy input (Fig. 3B and Supplementary file 2). Regarding HPH treatment, the highest degree of hydrolysis was achieved at the end of the hydrolysis time with $48.5 \%$. As already observed for biomass from flask cultivation (Fig. 3A and Supplementary file 1), the effect of PEF treatment and HPH treatment on the DH after 180 min was identical when the biomass was cultivated in the annular PBR.

\subsection{The effect of the type of protease on the hydrolysis reaction}

To get insight into the effect of each protease on the hydrolysis degree, the kinetics of hydrolysis was evaluated using untreated $S$. almeriensis biomass by Alcalase or Flavourzyme (Fig. 4 and Supplementary file 3). The degree of hydrolysis increased with the hydrolysis time for both proteases. However, the higher reaction rate was observed using Alcalase. Whereas Flavourzyme achieved $6,88 \%$ of the degree of hydrolysis after $180 \mathrm{~min}$ of hydrolysis, Alcalase obtained $46,75 \%$ of the degree of hydrolysis. This result indicated that the Alcalase is hydrolysing the majority of the peptide bonds.

\subsection{Incomplete hydrolysis caused by hydrophobic membrane proteins}

The reasons for the limited yield of EH were investigated by determining hydrophobic membrane proteins that were not hydrolysed at the end of the hydrolysis time using SDS-PAGE. Fig. 5A presents lanes of the supernatant after HPH treatment and before $\mathrm{EH}$, where the total protein inventory of $S$. almeriensis could be detected (lane 1), along with lanes of supernatant at the end of the hydrolysis time from untreated, PEF treated, and HPH treated samples. As can be seen in Fig. 5A, all supernatants from hydrolysed samples (lane 2-4) contain no protein. Also no protein bands could be detected when higher concentrations of supernatant were loaded. Thus, it can be concluded that a $3 \%(v / w)$ concentration of proteases is high enough for hydrolysing hydrophilic proteins. Furthermore, the residual biomass that has been separated from the supernatant after the $\mathrm{EH}$, was extracted using lysis buffer and analysed by $12 \%$ gel electrophoresis. The results are shown in Fig. $5 \mathrm{~B}$. Regardless of pre-treatment, all residual biomass samples contain considerable amounts of small proteins at the size of $15-20 \mathrm{kDa}$, and a

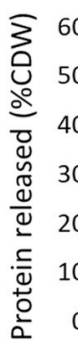
60
50
40
30
20
10
0 PEF treated $150 \mathrm{~kJ} \cdot \mathrm{kg}_{\text {sus }}{ }^{-1}$ (2h-incubated)
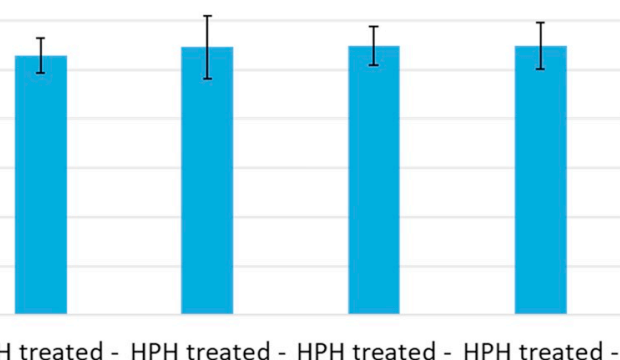

$\mathrm{HPH}$ treated - HPH treated - HPH treated - HPH treated - HPH treated $1 \mathrm{x}$
$2 \mathrm{x}$

Pre-treatment
Fig. 2. Effect of pre-treatment on the release of proteins from $S$. almeriensis after PEF-treatment and HPH-treatment. Large bars on HPH-treatment show the influence of repeated HPH-treatments 1 up to 5 successive passes from the left to the right. PEF treatment was done at $150 \mathrm{~kJ}^{\mathrm{k}} \mathrm{kg}_{\mathrm{sus}}{ }^{-1}$, followed by an incubation period of $2 \mathrm{~h}$, HPH treatment at 2 kbar. The experiment was repeated 3 times, and performed in duplicate. Error bars represent standard errors. 
A

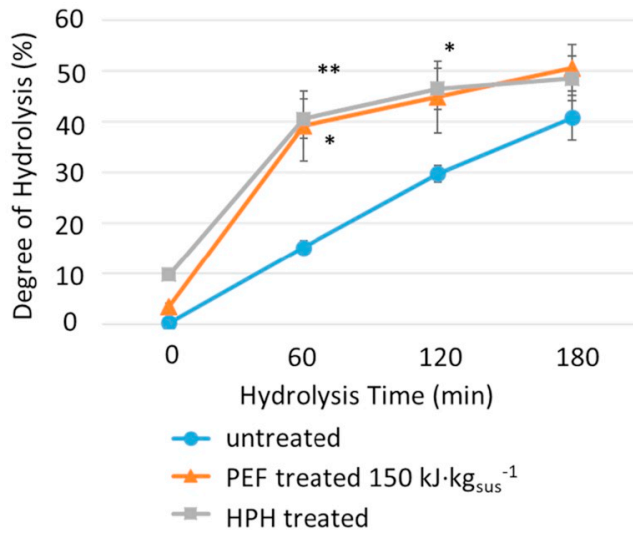

B

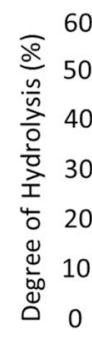

Fig. 3. Kinetics of the hydrolysis of $S$. almeriensis fresh biomass after PEF treatment, or $\mathrm{HPH}$ treatment using $3 \%(\mathrm{v} \cdot \mathrm{w})$ enzymes. (A) Kinetics of the hydrolysis of biomass at $50 \mathrm{~g} \cdot \mathrm{kg}_{\text {sus }}{ }^{-1}$ obtained from flasks. (B) Kinetics of the enzymatic hydrolysis of biomass at $80 \mathrm{~g} \cdot \mathrm{kg}_{\text {sus }}{ }^{-1}$ obtained from PBR. The experiment was performed in triplicate. Error bars represent standard errors. Asterisks indicate differences that are significant at $P=0.05\left({ }^{*}\right)$ or $P=0.01(* *)$, using a Student's $t$-test.

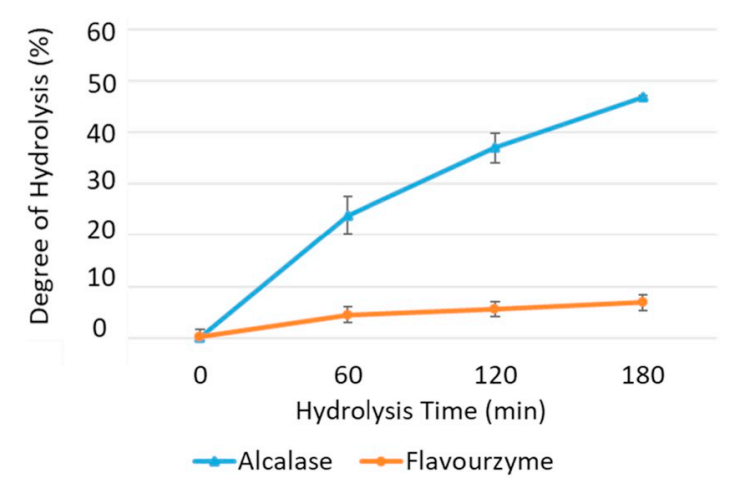

Fig. 4. Kinetics of the hydrolysis of $S$. almeriensis fresh biomass at $77 \mathrm{~g} \cdot \mathrm{kg}_{\text {sus }}{ }^{-1}$ by $3 \%(\mathrm{v} \cdot \mathrm{w})$ Alcalase or Flavourzyme. The experiment was performed in duplicate, error bars represent standard errors.

protein at the size of $25 \mathrm{kDa}$. The HPH treated sample shows the absence of two bands at approximate size of 50 and $150 \mathrm{kDa}$. There are also bands at $250 \mathrm{kDa}$ and higher with a weaker signal in the untreated sample, which can be interpreted as a result of aggregation.

3.6. Using the residual biomass after the enzymatic hydrolysis of PEFtreated microalgae biomass

For a sustainable microalgae biorefinery, it is necessary to use all

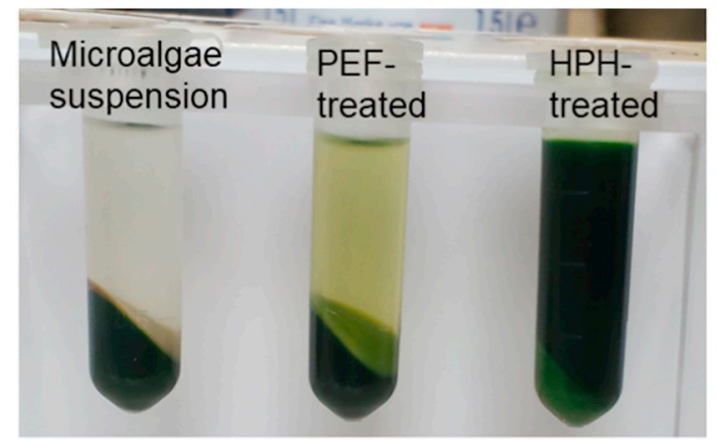

Fig. 6. PEF treatment versus conventional cell disruption by HPH. Demonstration of separability of the biomass by centrifugation under relevant industrial parameters $(2000 \times g)$.

valuable compounds (proteins, carbohydrates, lipids). However, conventional cell disruption methods produce a mixture of compounds that make the fractionation of different products quite difficult [32]. Figs. 6, 7 clearly indicate that PEF treatment maintains the overall structure of the cells as oppose to HPH treatment. The mixture of aggregates, cell wall fragments, and cell debris which are produced during HPH [15], cannot be separated by centrifugation under relevant industrial parameters $(2000 \times g$ ) (Fig. 6). On the contrary, PEF treatment is not an obstacle for a further separation of the residual biomass.

In this context, PEF treatment as a mild cell disruption method is
Supernatant after $180 \mathrm{~min} \mathrm{EH}$

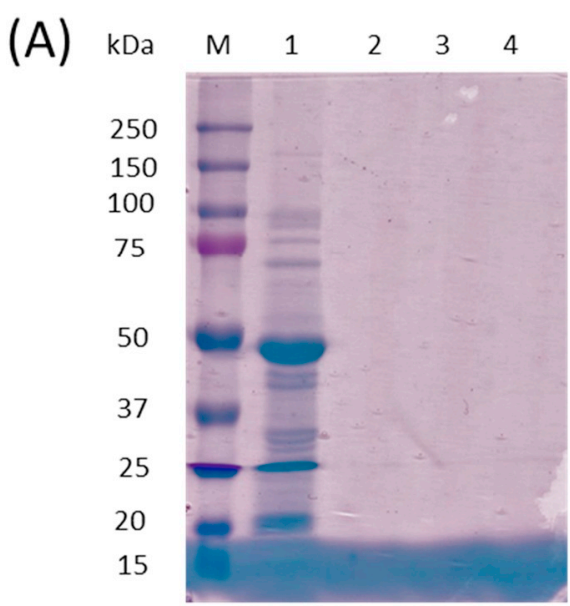

(B)

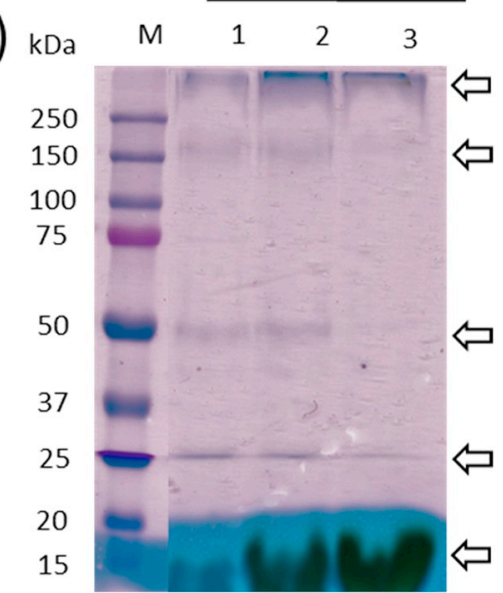

Fig. 5. SDS-PAGE Protein quality after the EH using untreated, PEF treated, and HPH treated S. almeriensis. $12 \%$ SDS-PAGE, loading volume $25 \mu \mathrm{l}$ of sample $+5 \mu \mathrm{l}$ of Precision Plus Protein standards ladder (M) on the left. Loaded samples include: (A) supernatant from HPH treated before the EH (1), supernatant after $180 \mathrm{~min}$ of $\mathrm{EH}$ from untreated (2), PEF treated (3), and HPH treated (4), and (B) residual biomass after $180 \mathrm{~min}$ of the $\mathrm{EH}$ from untreated (1), PEF treated (2), and HPH treated (3). The gel is representative for $n=2$ independent repetitions of the experiment. 

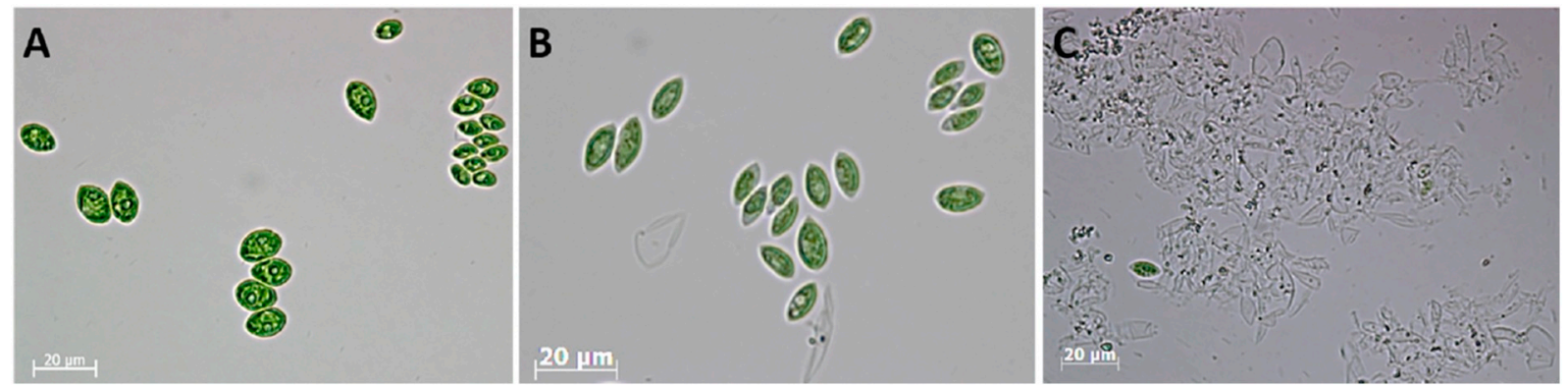

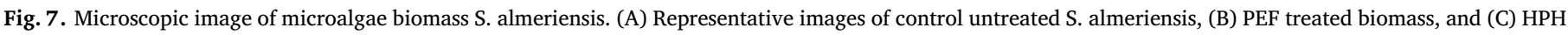
treated biomass. Scale bar represents $20 \mu \mathrm{m}$.

suggested as a promising technology for cascade processing of microalgae biomass. Even after the EH the supernatant that contains the free amino acids could be separated/collected from the residual biomass by centrifugation. The residual biomass with lower nitrogen content could still be utilized for other energetic purposes such as lipid extraction.

\section{Discussion}

Since proteins, like most other valuable microalgae compounds, are enclosed within a rigid cell wall, it is commonly recommended to apply a cell-wall-disrupting pre-treatment [11] prior to enzymatic hydrolysis. Efforts have been made to find methods which are not only energy efficient, but also free of chemical contamination [1]. In the current study, we investigated an alternative technique, i.e. PEF treatment, which targets on membrane permeabilization and does not disrupt the cell wall. The objective was to identify relevant processing parameters in order to increase the yield of the $\mathrm{EH}$ from microalgae proteins. In order to avoid energy-intensive drying processes, fresh biomass was utilized throughout this study.

\subsection{Conductivity increase after PEF treatment}

When applying PEF treatment to the biological cells, one of the first indications is an increase of cell suspension conductivity [1]. As shown in (Fig. 1), S. almeriensis causes an increase in the conductivity by a factor of 2 following PEF treatment in comparison to the untreated biomass at the biomass concentration of $97{\mathrm{~g} \cdot \mathrm{kg}_{\text {sus }}}^{-1}$ and the treatment energy of $150 \mathrm{~kJ} \cdot \mathrm{kg}_{\mathrm{sus}}{ }^{-1}$. Goettel et al. [1], and Silve et al. [22] showed an increase in conductivity by a factor of 1.5 and 2.5 after PEF treatment of Auxenochlorella protothecoides, respectively. A comparison of the obtained conductivity increase after PEF treatment of $S$. almeriensis with values obtained from the above mentioned studies confirms a high degree of membrane permeabilization of $S$. almeriensis by PEF-treatment with $1 \mu \mathrm{s}$ long pulses at $\mathrm{E}=40 \mathrm{kV} \cdot \mathrm{cm}^{-1}$ and an energy input of $150 \mathrm{~kJ} \cdot \mathrm{kg}_{\text {sus }}{ }^{-1}$. Furthermore, identical DH-values at $75 \mathrm{~kJ} \cdot \mathrm{kg}_{\text {sus }}{ }^{-1}$ (Fig. 3B) allow to conclude that a maximum degree of membrane permeabilization was achieved at $150 \mathrm{~kJ} \cdot \mathrm{kg}_{\text {sus }}{ }^{-1}$.

\subsection{Effect of pre-treatment and biomass condition on hydrolysis kinetics}

Progression of the DH over time was monitored for untreated, PEF treated and HPH treated biomass. DH at 0 min denotes the release of free amino acids after PEF or HPH treatment without impact of admixed enzymes. PEF treated biomass showed DH-values of about $3 \%$, whereas the highest DH was observed after HPH treatment which ranges between 8 and 10\% indicating that externalization of intracellular amino acids is highest with HPH treatment in comparison to PEF treatment. However, without pre-treatment at $0 \mathrm{~min}$, no free amino acid was detected in external medium indicated by a DH of $0 \%$.

For both cultivation conditions (flasks and PBR) and pre-treatments (PEF/HPH) performed in this study, the rate of increase of DH during the first $60 \mathrm{~min}$ is the same (Fig. 3B), or well comparable (Fig. 3A). The higher values obtained from HPH after $60 \mathrm{~min}$ are referred to the initial $\Delta \mathrm{DH}$ originated from the initially externalized amount of amino acids. Values of DH converge with increasing the time of hydrolysis and end at a value of close to $50 \%$ of $\mathrm{DH}$, although the amount of released proteins after PEF or HPH treatment was significantly different (Fig. 2). In other words, the maximum amount of intracellular proteins released into the suspension after HPH treatment, whereas following PEF treatment and $2 \mathrm{~h}$ of incubation only $1.15 \%$ of intracellular proteins were detected in the suspension. Thus, the amount of intracellular proteins released into the suspension after either pre-treatment does not affect the DH values. From the similar time course of DH values of PEF and HPH-treated samples, it can be concluded that for the case of PEF treatment, enzymes can penetrate into the cell and hydrolyse intracellular proteins as efficient as free accessible proteins after HPH can be hydrolysed. Maximum release of proteins by HPH does not provide a processing advantage in terms of a higher $\mathrm{DH}$.

Time course and DH-values are the same for flask $\left(\mathrm{CO}_{2}\right.$ limited $)$ and PBR cultivation indicating that the different cultivation conditions do not influence the EH process. Although PEF and HPH treatment provide well comparable values after $180 \mathrm{~min}$ of $\mathrm{EH}, 80 \%$ of final value can already be obtained after $60 \mathrm{~min}$, suggesting an advantage in terms of processing time after pre-treatment.

In contrast to pre-treated samples, DH of untreated biomass increases slower over time, and obtains only $15 \% \mathrm{DH}$ after $60 \mathrm{~min}$. Surprisingly, the final value is only $20 \%$ lower than the final value obtained from PEF or HPH treated biomass.

Romero Garcia et al. [11] reported about EH of freeze-dried S. almeriensis biomass at high concentrations $\left(200-350 \mathrm{~g}^{\mathrm{kg}} \mathrm{ksus}^{-1}\right.$ ) by adding $4 \%(v / v)$ enzymes consecutively. They obtained the higher degree of hydrolysis $(50 \%)$ using mechanical treatment by bead milling and adding the enzyme Viscozyme prior to hydrolysis while using biomass at high concentration $\left(>200 \mathrm{~g} \cdot \mathrm{l}^{-1}\right)$ for reducing the viscosity of the suspension. However, regarding untreated biomass, they obtained a degree of hydrolysis of only $13 \%$, which was significantly lower than the $\mathrm{DH}$ of their pre-treated biomass. The study therefore concluded for the necessity of a pre-treatment method for obtaining a higher degree of hydrolysis. With regard to the high $\mathrm{DH}$-values obtained in our study on wet and untreated biomass, it can be suggested that the reduced content of cytosolic water after freeze-drying impedes enzyme transport from the extracellular medium to intracellular proteins. This explains the low values of DH when freeze-dried and untreated biomass is utilized.

\subsection{Limiting factors of the enzymatic hydrolysis process}

It could be demonstrated that pre-treatment (either PEF or HPH) of wet Scenedesmus biomass considerably accelerates the hydrolysis reaction. Enzyme access to substrate is well comparable in yield and kinetics for membrane permeabilization (PEF) and cell disintegration by HPH as well (Fig. 3). Despite having achieved optimum pre-treatment conditions with both methods, a DH of only $50 \%$ could be obtained. 
SDS-PAGE analysis of the residual biomass confirmed the presence of significant amounts of proteins at a size of $25 \mathrm{kDa}, 50 \mathrm{kDa}$ and $150 \mathrm{kDa}$ after hydrolysis (Fig. 4). Most probable this unaffected protein fraction can be associated with membrane proteins, which are not accessible for enzymes. Intact membrane fragments, which enclose proteins, remain after $\mathrm{HPH}$ and PEF as well. Results from literature confirm that restricted enzyme-substrate reaction can be caused by the presence of the lipid compounds. Tchorbanov and Bozhkova [12] investigated the EH of proteins from Chlorella sp. and Scenedesmus incrassatulus biomass using solvent extraction as pre-treatment. They obtained an increased DH after ethanol extraction and concluded that removing the lipophilic compounds by ethanol prior to EH can improve the enzymesubstrate interactions. To increase DH, Morris et al. [33] also suggested an ethanolic extraction of microalgae biomass before $\mathrm{EH}$ of proteins. Thus lipid extraction prior to $\mathrm{EH}$ can be suggested as a measure to improve DH for our application.

$\mathrm{EH}$ of untreated wet biomass exhibits a slower kinetics of $\mathrm{DH}$. Nevertheless, with regard to untreated and fresh biomass a comparatively high DH of $40 \%$ could be obtained. Regarding the mechanism, the most reasonable explanation is that the catalytic activity of the proteases permeabilizes the cells, thus acting as a pre-treatment [2] by its own. Besides cellulose, pectin, agar, alginate, algaenen, fucans, and hemicellulose, glycoproteins also exist in the cell wall. Burczyk et al. [34] have determined the amino acids profile of cell wall proteins obtained from various strains of Chlorella and Scenedesmus. Voigt et al. [35] have investigated the polypeptide composition of the cell wall fractions from Scenedesmus obliquus. Their findings also confirm the presence of glycoproteins in the outer cell wall layers as well as in the inner cell wall layers.

From other work in literature, it is evident that proteases are utilized to hydrolyse the proteins of the cell membrane and cause subsequent cell degradation [2] (for review see [36]). Liang et al. [37] also reported that the treatment of sonicated microalgae with alkaline proteases and neutral proteases improved the lipid recovery. The latter was attributed to the hydrolysis of membrane proteins, which led to additional cell disruption. Based on these facts it can be concluded, that in the case of wet and untreated biomass cell wall and membrane proteins are hydrolysed which leads to increased permeability of the cell boundary, enabling enzyme access to intracellular protein substrates. This process of cell boundary degradation may also apply for freeze-dried and untreated biomass, but here, the lack of intracellular water hinders efficient enzyme transport to intracellular proteins.

A possible contribution of endogenous proteolytic activity for amino acid production, e.g. by activation of intracellular proteases, can be excluded since incubation of untreated $S$. almeriensis biomass at $50{ }^{\circ} \mathrm{C}$ and $\mathrm{pH} 8$ for $180 \mathrm{~min}$ without enzyme admixture lead to a maximum DH of only $2 \%$ (data not shown) at the end of the incubation time. Adding external proteases is mandatory to achieve reasonable degrees of hydrolysis.

Based on above discussions, regardless of feasibility, approaches for increasing DH in further studies are liberation of proteins from lipophilic environments, e.g. by preceding solvent based lipid extraction. Solubilization agents and aggregation suppressors such as SDS might also improve DH. Unfortunately, such additives are not only toxic, but also incompatible with protease activity.

\subsection{PEF pre-treatment is effective even at low treatment energy}

Efficiency of PEF treatment is known to depend on the specific energy input $[1,22]$. Further reduction of the PEF treatment energy to $75 \mathrm{~kJ} \mathrm{~kg}_{\text {sus }}{ }^{-1}$ has been investigated in this study. Hydrolysis kinetics and the final value of DH were identical for PEF treatments at an energy input of $75 \mathrm{~kJ} \cdot \mathrm{kg}_{\text {sus }}{ }^{-1}$ and $150 \mathrm{~kJ} \cdot \mathrm{kg}_{\text {sus }}{ }^{-1}$ (see Fig. 3). In consequence, at a biomass density of $100 \mathrm{~g} \cdot \mathrm{kg}_{\text {sus }}{ }^{-1}$ a PEF treatment energy of $150 \mathrm{~kJ} \cdot \mathrm{kg}_{\text {sus }}{ }^{-1}$ and $75 \mathrm{~kJ} \cdot \mathrm{kg}_{\text {sus }}{ }^{-1}$ correspond to $1.5 \mathrm{MJ} \cdot \mathrm{kg}_{\mathrm{dw}}$ and $0.75 \mathrm{MJ} \cdot \mathrm{kg}_{\mathrm{dw}}$. Thus, it can be concluded that using the lower energy input at $75 \mathrm{~kJ} \cdot 1^{-1}$ also leads to adequate permeabilization prior to $\mathrm{EH}$. Our results revealed the advantage of performing PEF at lower energy input along with a higher concentration of cells that together reduce the energy demand of PEF treatment per kg of dry biomass.

\section{Conclusion}

PEF treatment of $S$. almeriensis biomass accelerates enzymatic hydrolysis. PEF treatments at an energy input of $75 \mathrm{~kJ}^{\circ} \mathrm{kg}_{\text {sus }}^{-1}$ and $150 \mathrm{~kJ} \cdot \mathrm{kg}_{\text {sus }}{ }^{-1}$ reveal the same hydrolysis kinetics and the same final value of $\mathrm{DH}$ of $48 \% \pm 2 \%$. Consequently, the required PEF treatment energy at a biomass density of $80 \mathrm{~g} \cdot \mathrm{kg}_{\text {sus }}{ }^{-1}$ amounts to $<0.93 \mathrm{MJ} \cdot \mathrm{kg}_{\mathrm{dw}}$, which is lower than the energy consumed for HPH in this study. HPH pre-treatment did not exhibit processing advantages over PEF-treatment in terms of $\mathrm{DH}$ and hydrolysis kinetics. Both pre-treatment methods allow shortening of $\mathrm{EH}$ processing time, since $80 \%$ of the maximum DH can already be achieved after 60 min of hydrolysis time, whereas $180 \mathrm{~min}$ of hydrolysis time were needed for untreated biomass to reach $80 \%$ of maximum DH. Moreover, if efficiency losses to $80 \%$ of the maximum DH can be tolerated in an industrial process, EH can be performed with pre-treatment for only $60 \mathrm{~min}$ or without pre-treatment for $180 \mathrm{~min}$ at comparable yields.

Based on identical time courses of DH for PEF and HPH pre-treatment as well, it can be concluded that membrane permeabilisation by PEF enables enzyme entry into the cells and, furthermore, that protein hydrolysis after PEF is as efficient as in the case of free accessible proteins after $\mathrm{HPH}$.

Incomplete protein hydrolysis was confirmed by SDS-PAGE monitoring of the residual protein content after $\mathrm{EH}$. In conclusion, optimization of the utilized enzyme cocktail or removal of lipids prior to EH is required if higher DHs are targeted.

In contrast to $\mathrm{HPH}, \mathrm{PEF}$-pretreatment allows cascade processing of Scenedesmus biomass for additional component recovery, since residual biomass is not disrupted after PEF and can be separated efficiently by low-g-centrifugation (Figs. 6, 7). Future work will focus on exploitation of this unique characteristic of PEF treatment, e.g. for additional recovery of valuable substances.

\section{Declaration of competing interest}

The authors declare no conflict of interest.

\section{Acknowledgements}

This work was conducted in the framework and financed by the Helmholtz Research Program on Renewable Energies [Topic 3: Bioenergy] and by SABANA-project of the European Union's Horizon 2020 Research and Innovation program [Grant Agreement No. 727874]. We thank Rüdiger Wüstner, Klaus Leber, and Natalja Nazarova for technical support. Additionally, the authors thank Ralf Strässner for considerable advices and deep involvement. Professor F.G. Acien Fernandez, University of Almeria, Spain, kindly provided the $S$. almeriensis inoculum.

\section{Author contributions}

Conception and design of the experiments: SA, CG, AS, GM, WF. Experiments: SA, DSS, EN-L, WF. Draft of this article: SA. Revision of this article: CG, AS, GM, EM, WF.

SA takes responsibility for the integrity of this work.

\section{Appendix A. Supplementary data}

Supplementary data to this article can be found online at https:// doi.org/10.1016/j.algal.2019.101656. 


\section{References}

[1] M. Goettel, C. Eing, C. Gusbeth, R. Straessner, W. Frey, Pulsed electric field assisted extraction of intracellular valuables from microalgae, Algal Res. 2 (2013) 401-408, https://doi.org/10.1016/j.algal.2013.07.004.

[2] E. Günerken, E. D'Hondt, M.H.M. Eppink, L. Garcia-Gonzalez, K. Elst, R.H. Wijffels, Cell disruption for microalgae biorefineries, Biotechnol. Adv. 33 (2015) 243-260, https://doi.org/10.1016/j.biotechadv.2015.01.008.

[3] E.W. Becker, Micro-algae as a source of protein, Biotechnol. Adv. 25 (2007) 207-210, https://doi.org/10.1016/j.biotechadv.2006.11.002

[4] C. Paungfoo-Lonhienne, T.G.A. Lonhienne, D. Rentsch, N. Robinson, M. Christie, R.I. Webb, H.K. Gamage, B.J. Carroll, P.M. Schenk, S. Schmidt, Plants can use protein as a nitrogen source without assistance from other organisms, Proc. Natl. Acad. Sci. U. S. A. 105 (2008) 4524-4529, https://doi.org/10.1073/pnas. 0712078105.

[5] C. Schreiber, H. Schiedung, L. Harrison, C. Briese, B. Ackermann, J. Kant, S.D. Schrey, D. Hofmann, D. Singh, O. Ebenhöh, W. Amelung, U. Schurr, T. MettlerAltmann, G. Huber, N.D. Jablonowski, L. Nedbal, Evaluating potential of green alga Chlorella vulgaris to accumulate phosphorus and to fertilize nutrient-poor soil substrates for crop plants, J. Appl. Phycol. 19 (2018) 529, https://doi.org/10.1007/ s10811-018-1390-9.

[6] J. Garcia-Gonzalez, M. Sommerfeld, Biofertilizer and biostimulant properties of the microalga Acutodesmus dimorphus, J. Appl. Phycol. 28 (2016) 1051-1061, https:// doi.org/10.1007/s10811-015-0625-2.

[7] M. Fountoulakis, H.-W. Lahm, Hydrolysis and amino acid composition analysis of proteins, J. Chromatogr. A 826 (1998) 109-134, https://doi.org/10.1016/S0021 9673(98)00721-3.

[8] R.E. Aluko, Antihypertensive peptides from food proteins, Annu. Rev. Food Sci. Technol. 6 (2015) 235-262, https://doi.org/10.1146/annurev-food-022814015520.

[9] A. Sila, A. Bougatef, Antioxidant peptides from marine by-products: isolation, identification and application in food systems. A review, J. Funct. Foods 21 (2016) 10-26, https://doi.org/10.1016/j.jff.2015.11.007.

[10] S.Y. Lee, S.J. Hur, Antihypertensive peptides from animal products, marine organisms, and plants, Food Chem. 228 (2017) 506-517, https://doi.org/10.1016/j. foodchem.2017.02.039.

[11] J.M. Romero García, F.G. Acién Fernández, J.M. Fernández Sevilla, Development of a process for the production of $\mathrm{L}$-amino-acids concentrates from microalgae by enzymatic hydrolysis, Bioresour. Technol. 112 (2012) 164-170, https://doi.org/10. 1016/j.biortech.2012.02.094.

[12] B. Tchorbanov, M. Bozhkova, Enzymatic hydrolysis of cell proteins in green algae Chlorella and Scenedesmus after extraction with organic solvents, Enzym. Microb. Technol. 10 (1988) 233-238, https://doi.org/10.1016/0141-0229(88)90072-5.

[13] H.J. Morris, O. Carrillo, A. Almarales, R.C. Bermúdez, Y. Lebeque, R. Fontaine, G. Llauradó, Y. Beltrán, Immunostimulant activity of an enzymatic protein hydrolysate from green microalga Chlorella vulgaris on undernourished mice, Enzym. Microb. Technol. 40 (2007) 456-460, https://doi.org/10.1016/j.enzmictec.2006. 07.021 .

[14] B.M. Plaza, C. Gómez-Serrano, F.G. Acién-Fernández, S. Jimenez-Becker, Effect of microalgae hydrolysate foliar application (Arthrospira platensis and Scenedesmus sp.) on Petunia x hybrida growth, J. Appl. Phycol. 25 (2018) 154, https://doi.org/ 10.1007/s10811-018-1427-0.

[15] B.H.J. Yap, S.A. Crawford, G.J. Dumsday, P.J. Scales, G.J.O. Martin, A mechanistic study of algal cell disruption and its effect on lipid recovery by solvent extraction, Algal Res. 5 (2014) 112-120, https://doi.org/10.1016/j.algal.2014.07.001.

[16] P.R. Postma, T.L. Miron, G. Olivieri, M.J. Barbosa, R.H. Wijffels, M.H.M. Eppink, Mild disintegration of the green microalgae Chlorella vulgaris using bead milling, Bioresour. Technol. 184 (2015) 297-304, https://doi.org/10.1016/j.biortech.2014. 09.033

[17] T. Kotnik, W. Frey, M. Sack, S. Haberl Meglič, M. Peterka, D. Miklavčič, Electroporation-based applications in biotechnology, Trends Biotechnol. 33 (2015) 480-488, https://doi.org/10.1016/j.tibtech.2015.06.002.

[18] W. Frey, C. Gusbeth, T. Sakugawa, M. Sack, G. Mueller, J. Sigler, E. Vorobiev, N. Lebovka, I. Álvarez, J. Raso, L.C. Heller, M.A. Malik, C. Eing, J. Teissie, Environmental applications, food and biomass processing by pulsed electric fields, in: H. Akiyama, R. Heller (Eds.), Bioelectrics, Springer Japan, Tokyo, 2017, pp.
$389-476$

[19] J.F. Sánchez, J.M. Fernández-Sevilla, F.G. Acién, M.C. Cerón, J. Pérez-Parra E. Molina-Grima, Biomass and lutein productivity of Scenedesmus almeriensis: influence of irradiance, dilution rate and temperature, Appl. Microbiol. Biotechnol. 79 (2008) 719-729, https://doi.org/10.1007/s00253-008-1494-2.

[20] I. Fernández, J.L. Guzmán, M. Berenguel, F.G. Acién, Dynamic modeling of microalgal production in photobioreactors, in: B.N. Tripathi, D. Kumar (Eds.), Prospects and Challenges in Algal Biotechnology, Springer Singapore, Singapore, 2017, pp. 49-87.

[21] D.I. Arnon, B.D. McSwain, H.Y. Tsujimoto, K. Wada, Photochemical activity and components of membrane preparations from blue-green algae. I. Coexistence of two photosystems in relation to chlorophyll a and removal of phycocyanin, Biochimica et Biophysica Acta (BBA) - Bioenergetics 357 (1974) 231-245, https://doi.org/10. 1016/0005-2728(74)90063-2.

[22] A. Silve, C.B. Kian, I. Papachristou, C. Kubisch, N. Nazarova, R. Wüstner, K. Leber, R. Strässner, W. Frey, Incubation time after pulsed electric field treatment of microalgae enhances the efficiency of extraction processes and enables the reduction of specific treatment energy, Bioresour. Technol. 269 (2018) 179-187, https://doi. org/10.1016/j.biortech.2018.08.060.

[23] C. Eing, M. Goettel, R. Straessner, C. Gusbeth, W. Frey, Pulsed electric field treatment of microalgae-benefits for microalgae biomass processing, IEEE Trans. Plasma Sci. 41 (2013) 2901-2907, https://doi.org/10.1109/TPS.2013.2274805.

[24] S. Grimnes, Ø.G. Martinsen, Bioimpedance and Bioelectricity Basics, Academic press, London, England, 2015.

[25] O.H. Lowry, N.J. Rosebrough, A.L. Farr, R.J. Randall, Protein measurement with the Folin phenol reagent, J. Biol. Chem. 193 (1951) 265-275.

[26] T. Rausch, The estimation of micro-algal protein content and its meaning to the evaluation of algal biomass I. Comparison of methods for extracting protein, Hydrobiologia 78 (1981) 237-251, https://doi.org/10.1007/BF00008520.

[27] J.K. McDonald, An overview of protease specificity and catalytic mechanisms: aspects related to nomenclature and classification, Histochem. J. 17 (1985) 773-785.

[28] M. Merz, T. Eisele, P. Berends, D. Appel, S. Rabe, I. Blank, T. Stressler, L. Fischer, Flavourzyme, an enzyme preparation with industrial relevance: automated ninestep purification and partial characterization of eight enzymes, J. Agric. Food Chem. 63 (2015) 5682-5693, https://doi.org/10.1021/acs.jafc.5b01665.

[29] P.M. Nielsen, D. Petersen, C. Dambmann, Improved method for determining food protein degree of hydrolysis, J. Food Sci. 66 (2001) 642-646, https://doi.org/10. 1111/j.1365-2621.2001.tb04614.x.

[30] U.K. LAEMMLI, Cleavage of structural proteins during the assembly of the head of bacteriophage T4, Nature 227 (1970), https://doi.org/10.1038/227680a0 (680 EP)

[31] G. Candiano, M. Bruschi, L. Musante, L. Santucci, G.M. Ghiggeri, B. Carnemolla, P. Orecchia, L. Zardi, P.G. Righetti, Blue silver: a very sensitive colloidal Coomassie G-250 staining for proteome analysis, Electrophoresis 25 (2004) 1327-1333, https://doi.org/10.1002/elps.200305844.

[32] C. Posten, C. Walter, Microalgal Biotechnology: Integration and Economy, 1st ed., Walter de Gruyter GmbH Co.KG, s.1, 2012.

[33] H.J. Morris, A. Almarales, O. Carrillo, R.C. Bermúdez, Utilisation of Chlorella vulgaris cell biomass for the production of enzymatic protein hydrolysates, Bioresour. Technol. 99 (2008) 7723-7729, https://doi.org/10.1016/j.biortech.2008.01.080.

[34] J. Burczyk, B. Śmietana, K. Termińska-Pabis, M. Zych, P. Kowalowski, Comparison of nitrogen content amino acid composition and glucosamine content of cell walls of various chlorococcalean algae, Phytochemistry 51 (1999) 491-497, https://doi. org/10.1016/S0031-9422(99)00063-1.

[35] J. Voigt, A. Stolarczyk, M. Zych, P. Malec, J. Burczyk, The cell-wall glycoproteins of the green alga Scenedesmus obliquus. The predominant cell-wall polypeptide of Scenedesmus obliquus is related to the cell-wall glycoprotein gp3 of Chlamydomonas reinhardtii, Plant Sci. 215-216 (2014) 39-47, https://doi.org/10 1016/j.plantsci.2013.10.011.

[36] J. Velazquez-Lucio, R.M. Rodríguez-Jasso, L.M. Colla, A. Sáenz-Galindo, D.E. Cervantes-Cisneros, C.N. Aguilar, B.D. Fernandes, H.A. Ruiz, Microalgal biomass pretreatment for bioethanol production: a review, Biofuel Res. J. 5 (2018) 780-791, https://doi.org/10.18331/BRJ2018.5.1.5.

[37] K. Liang, Q. Zhang, W. Cong, Enzyme-assisted aqueous extraction of lipid from microalgae, J. Agric. Food Chem. 60 (2012) 11771-11776, https://doi.org/10. 1021/jf302836v. 